\title{
Variation in Species Richness and other Vegetational Parameters in Pine and Mixed Broadleaf Forest of Central Himalaya
}

\author{
Neeta Arya* and Jeet Ram
}

\author{
Department of Forestry and Environmental Science, Kumaun University, Nainital, India \\ Email- neetaaryadr@gmail.com
}

\begin{abstract}
In the present study total two forest stand on different canopy cover (open canopy, moderate canopy and close canopy) were studied to assess the importance of these two parameters in supporting species regeneration and biodiversity in a $P$. roxburghii forest and mixed broadleafforest between 1300 and $2000 \mathrm{~m}$ elevation in the Utrarakhand Himalaya. Tree species richness was high in mixed broadleaf forest compared to $P$. roxburghii forest. While, shrub and herb species richness was high in $P$. roxburghii forest. The tree and herb density was significantly high in mixed broadleafforest. Tree shrub and herb diversity was high in mixed broadleaf forest. These forests are exploited variously for different resources and consequently the vegetation cover is decreasing. The disturbances are changing the species richness and diversity, which influences the soil and environmental conditions. Thus, the conservation and management of these forests will be important for the sustainability of human and land. Disturbances and climate change will alter the species composition of these forests, which may shift socio-economic and ecological condition of the region. Keywords-Forest, canopy cover, richness and diversity.
\end{abstract}

\section{INTRODUCTION}

Himalayan vegetation is subjected to various types of disturbances and most of them are either geological or anthropogenic or both. The geological disturbances are natural and include landslides, soil erosion and earth quakes where as the anthropogenic disturbances include deforestation, grazing, lopping of tree branches for fodder and fuel wood, removal of leaf and wood litter from the forest floor and frequent fire. Both types of disturbances affect ecosystem stability and retard the successional process (Kumar and Ram 2005). Disturbances favour plant invasion because they provide a pulse of resources for seedling establishment and growth (Pausas et al. 2006 and Arya et al. 2012). Tree of $P$. roxburghii, the dominant species from low to mid elevation, were harvested on a large-scale in 1960s and 1970s for timber and other industrial raw material and thereafter the continued disturbances either geological or anthropogenic is severely threatening the biological diversity (Singh 1998). Forest biodiversity is the main source of livelihood of the people living in Uttarakhand, Central Himalaya. The forests of this region are mainly dominated by Pinus roxburghii Sarg. (Chir Pine) and Quercus leucotrichophora A. Camus. (Banj oak). Chir pine often forms a pure stand in this area, but sometime it also mixes with certain broadleaved species like Q. leucotrichophora, Q. glauca Thumb, Pyrus pashia Ham., Myrica esculanta Linn. and Rhododentron arboreum $\mathrm{Sm}$.

Himalayan biodiversity is severely threatened by natural and anthropogenic disturbances. Anthropogenic disturbances play an important role to change, loss or maintenance of plant biodiversity and more recent phenomenon of climate change is also responsible for the change in species composition and other ecosystem activities (Ram et al. 2005). The forest vegetation of Uttarakhand Himalaya has been described by different workers. These are Tewari and Singh (1981), Saxena and Singh (1982), Ralhan et al. (1982), Kalakoti et al. (1986), Sinhg and Singh (1987), Sundriyal and Bisht (1988), Tewari et al. (1989), Singh and Singh (1992), Pathak et al. (1993), Dhaulkandi (1996). Recently, Kumar (2000), Khera et al. (2001), Kharkwal (2002), Ram et al. (2004), Mishra et al. (2004), Ku mar and Ram (2005), Sagar and Singh (2005), Samant and Joshi (2005), Semwal (2006), Lal (2007), Singh et al. (2008), Giri et al. (2008), Arya and Ram (2013), Singh et al. (2014) annd Pandey et al. (2014 4, b) have described various vegetational parameters of the Himalayan forest in relation to biodiversity. The present study deals with vegetational analysis and species diversity across the canopy cover and comparison of diversity between pine dominated and mixed broadleaf forests. 


\section{MATERIAL AND METHODS}

The study area is located between $29^{\circ} 20^{\prime}$ and $29^{\circ} 30^{\prime} \mathrm{N}$ latitude and $79^{\circ} 23^{\prime}$ and $79^{\circ} 42^{\prime}$ E longitude at elevation $1350-2000 \mathrm{~m}$ in Uttarakhand Himalaya. Altitudinally, Nain ital is located in temperate zone of the Himalaya. Chirpine (Pinus roxburghii) and chir-pine mixed broadleaf forest were selected for the detailed study of plant biodiversity and other vegetational parameters.

The monsoon climate is prevalent in the region. The minimum temperature varied from $5.0^{\circ} \mathrm{C}$ (January) to $17.4^{0} \mathrm{C}$ (June) and maximum temperature from $12.5^{\circ} \mathrm{C}$ (January) to $17.4^{0} \mathrm{C}$ (June). The total annual rainfall varied 1486.8 to $2213.4 \mathrm{~mm}$. The mean monthly rainfall (average of three years) was $2.25 \mathrm{~mm}$ (November) and $498.5 \mathrm{~mm}$ (July). The rocks of the study area are mainly sandstone, conglomeration, limestone, quartzite, schist's and granites (Valdiya, 1980).

A total of two forest types were selected with three different canopy treatment (open canopy $<30 \%$, moderate canopy 30 $60 \%$ and close canopy $>60 \%$ ) were identified for the detailed study of vegetation parameters. In each forest, almost all species present (>90\%) were collected, preserved, brought to the laboratory and identified with the help of plant taxonomist and flora. Species richness were determined as the number of species per unite area (Whittaker 1972, 1975). Vegetation analysis was made for all the three layers of forest, i.e. trees, shrubs and herbs. The size and number of samples were determined following Saxena and Singh (1982). The vegetation analysis was done by sampling $20,10 \times 10 \mathrm{~m}$ quadrats on each site for tree. The shrub layer was analysed by sampling 20 quadrats of $5 \times 5 \mathrm{~m}$ and herb layer by placing 20 quadrats of $1 \times 1 \mathrm{~m}$ randomly at each site. The vegetation data were calculated for density, frequency and abundance (Curtis and McIntosh, 1950). The $\mathrm{CBH}$ (circumference at breast height, $1.37 \mathrm{~m}$ ) was used to calculate the basal area. The covers of shrub were measured by taking line transect of $5 \mathrm{~m}$. Herb cover were determined by placing a transect of $1 \mathrm{~m}$ on the ground and percent ground cover occupied by each herb species was noted avoiding overlapping (Mishra 1968).The diversity index for all the three layers at each study site was calculated by using Shannon-Wiener diversity index (Shannon and weaver, 1963) using by density data, concentration of dominance by using Simpson's index (Simpson, 1949) and Evenness (Pielou, 1966) were also computed.

The index of the similarity (S) was calculated to compare the two forests (Sorensen, 1948) as:

\section{$\mathrm{S}=\mathbf{2 C} / \mathrm{A}+\mathrm{B} \times 100$}

Where, $A$ and $B$ represent the number of species in forest $A$ and $\mathrm{B}$, respectively and $\mathrm{C}$ is the number of species common to both the stands.

\section{RESULT}

\section{Mixed broadleaf forest}

A total of 192 species were recorded in close canopy, moderate canopy and open canopy of mixed broadleaf forest, among which 30 were trees, 45 were shrubs and 117 were herbs. The highest tree richness (26 species) was found in moderate canopy forest while close and open canopy forest recorded 25 and 22 tree species, respectively. In case of shrub, richness was highest in close canopy (38 species) compared to moderate and open canopy forest. Herbaceous species were also highest in moderate canopy ( 84 species) forest followed by close canopy ( 82 species) forest and lowest in open canopy (76 species) forest. The highest tree density (398 trees/ha) was found in close canopy forest and which decreased with increased disturbance level, 356 trees/ha in moderate canopy forest and 321.5 trees/ha in open canopy forest. In case of shrub species, Eupatorium cannabinum was dominant in open canopy forest and close canopy forest where as Maesa indica was dominating in moderate canopy forest. The tree density was significantly varied from moderate-close canopy and close-open canopy $(\mathrm{p}<0.01)$. Shrub density was highest (25683.4 shrub/ha) in close canopy forest whereas the lowest (23042.9shrub/ha) density was recorded in moderate canopy forest. It was significantly varied from open-moderate, moderate-close and close-open canopy cover ( $\mathrm{p}<0.01$ ). A mong herbs, Carex nubigena and Justicea simplex was dominating in open canopy forest. Polygonum fulganes was dominating in moderate canopy forest and Oplismenus compositus was dominating in close canopy forest, close canopy forest was most dense with 7921183.4 herbs/ha compared to moderate and open canopy forest. Herb density was significantly varied from open-moderate, moderate-close and close-open canopy cover $(\mathrm{p}<0.01)$ (Table 1). 
Table.1: Various vegetational parameters along disturbance gradients in P. roxburghii and mixed broadleafforest.

\begin{tabular}{|c|c|c|c|c|c|c|}
\hline & \multicolumn{3}{|c|}{ Pinus roxburghii Forest } & \multicolumn{3}{|c|}{ Mixed broadleaf Forest } \\
\hline & $\begin{array}{c}\text { Close } \\
\text { Canopy }\end{array}$ & $\begin{array}{c}\text { Moderate } \\
\text { Canopy }\end{array}$ & $\begin{array}{c}\text { Open } \\
\text { Canopy }\end{array}$ & $\begin{array}{c}\text { Close } \\
\text { Canopy }\end{array}$ & $\begin{array}{c}\text { Moderate } \\
\text { Canopy }\end{array}$ & $\begin{array}{c}\text { Open } \\
\text { Canopy }\end{array}$ \\
\hline \multicolumn{7}{|c|}{ Tree } \\
\hline Species Richness & 8 & 14 & 12 & 25 & 26 & 22 \\
\hline Density (trees/ha) & 355.0 & 299.0 & 294.0 & 398.0 & 356.0 & 321.5 \\
\hline Shannon Diversity Index (H) & 0.69 & 0.80 & 0.89 & 2.11 & 1.91 & 1.71 \\
\hline Simps on Index (CD) & 0.74 & 0.72 & 0.68 & 0.31 & 0.36 & 0.37 \\
\hline Evenness & 0.12 & 0.21 & 0.16 & 0.43 & 0.41 & 0.29 \\
\hline \multicolumn{7}{|c|}{ Shrubs } \\
\hline Species Richness & 35 & 37 & 33 & 38 & 33 & 32 \\
\hline Density (shrubs/ha) & 27773.4 & 29239.9 & 30887.1 & 25683.4 & 23042.9 & 25513.3 \\
\hline Shannon Diversity Index (H) & 3.22 & 3.28 & 2.89 & 3.21 & 3.12 & 3.16 \\
\hline Simps on Index (CD) & 0.137 & 0.162 & 0.194 & 0.177 & 0.181 & 0.174 \\
\hline Evenness & 0.049 & 0.042 & 0.035 & 0.052 & 0.055 & 0.054 \\
\hline \multicolumn{7}{|c|}{ Herbs } \\
\hline Species Richness & 104 & 105 & 116 & 82 & 84 & 76 \\
\hline Density (herbs/ha) & 3524080.8 & 3485394.9 & 4140229.3 & 7921183.4 & 6170537.9 & 7212821.8 \\
\hline Shannon Diversity Index (H) & 4.06 & 4.09 & 4.11 & 5.53 & 5.40 & 5.63 \\
\hline Simps on Index (CD) & 0.083 & 0.077 & 0.077 & 0.336 & 0.413 & 0.903 \\
\hline Evenness & 0.073 & 0.071 & 0.071 & 0.174 & 0.157 & 0.172 \\
\hline Cover (\%) & 82.2 & 56.6 & 27.6 & 81.9 & 56.3 & 27.9 \\
\hline
\end{tabular}

Shannon diversity index for tree species varied between 1.71 and 2.11 and the minimum and maximum value were observe for open canopy and close canopy forest, respectively. It was opposite for Simpson dominance index. Simpson index was recorded highest $(0.37)$ for tree species in open canopy forest followed by close canopy (0.31) and moderate canopy (0.36) forest. The tree diversity was significantly varied from open-moderate canopy and closeopen canopy $(p<0.01)$. Whereas in case of shrub the Shannon diversity index was highest (3.21) in close canopy compared to moderate (3.12) canopy and open canopy (3.12) forest. It was significantly varied from openmoderate, moderate-close and close-open canopy $(\mathrm{p}<0.01)$. For herb species, the Shannon diversity index was highest in open canopy (5.63) compared to moderate canopy (5.40) and close canopy (5.53) forest. Herb diversity was significantly varied from one canopy cover to another $(\mathrm{p}<0.01)$. While, Simpson index was also found in increasing order (0.336 for close canopy, 0.413 for moderate canopy and 0.903 for open canopy). The evennes $s$ index for tree species was found highest in close canopy (0.43) and it was recorded lowest (0.29) at intermediate level of disturbances. The higher the values of evenness index, the more even the species are in their distribution. Thus, close canopy stand has more even distribution than moderate and open canopy, even though they have more species richness than disturbed stand (Table 1). The relationship between the canopy cover and species richness indicated that the shrub richness was negatively related with canopy cover while herb richness was positively correlated with all canopy cover (fig. 1). 

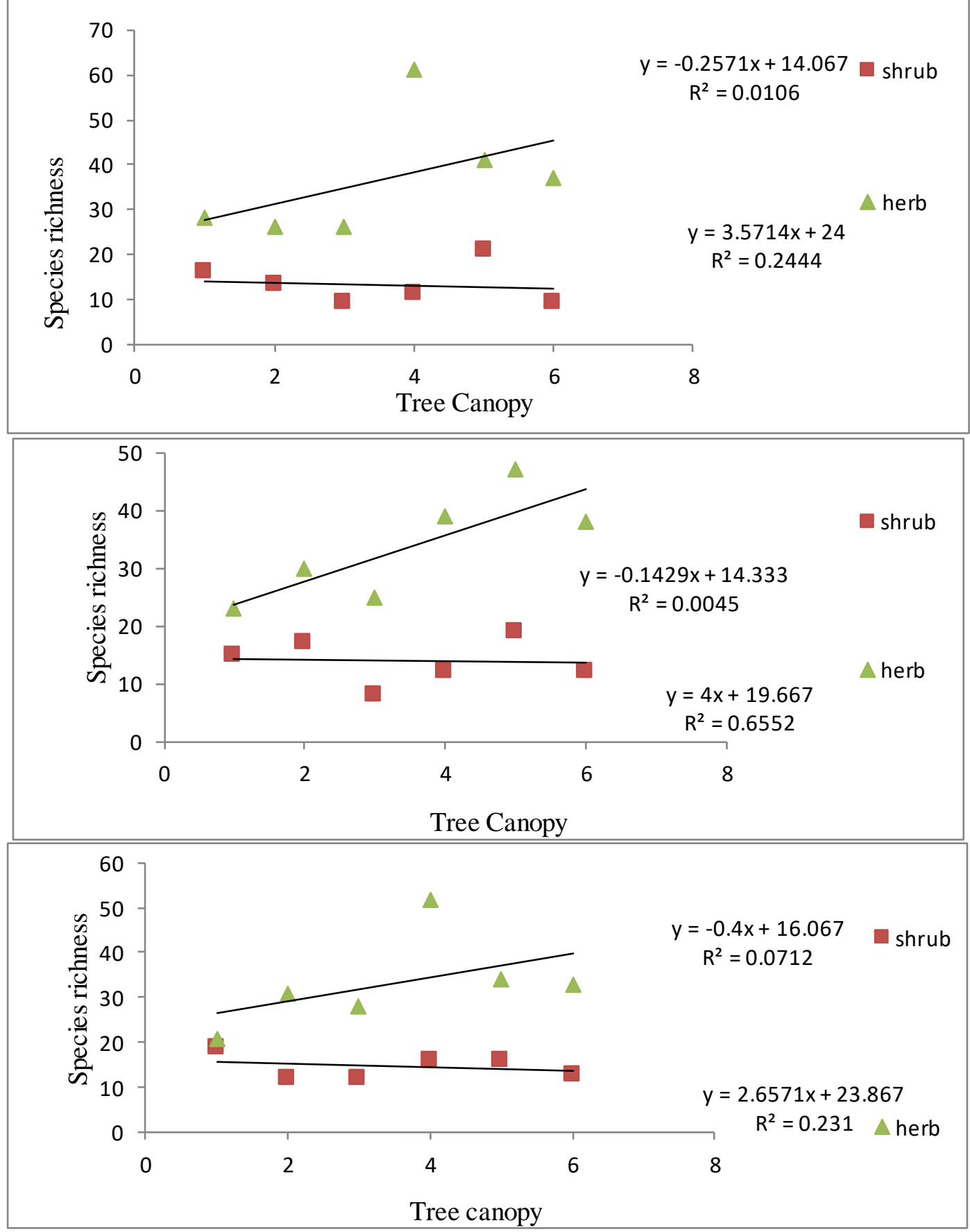

\section{A. Open canopy B. Moderate canopy C. Close canopy}

Fig.1: Relationship between tree canopy cover and shrub \& herb species richness in mixed broadleafforest

\section{Pinus roxburghii Forest}

A total of 201 species were recorded in pine forest of Nainital, among which 19 were trees, 44 were shrubs and 138 were herbs. A mong herbs, Oplismenus composites was dominating in close canopy forest, Polygonum fulgans was dominating in moderate canopy forest. While Carex nubigena and Justicea simplex dominate in open canopy forest. It was significantly varied from one canopy cover to another $(\mathrm{p}<0.01)$. The dominant species were identified on the basis of individual numbers. Maximu m tree species (14) were recorded at intermediate level of disturbance followed by close canopy (8) and open canopy (12) forest. In case of shrub, richness was highest in moderate canopy (37) compared to close canopy (35) and open canopy (33) forest. Tree density ranged from 294.0 trees/ha in open canopy to 355.0 trees/ha in close canopy forest. The tree density was significantly varied from one canopy cover to another $(\mathrm{p}<0.01)$. In case of shrub species Eupatorium cannabinum 
was dominant at all three level of disturbances followed by

Berbaris asiatica, Lantana camara, Rubus ellipticus and Myrsine affricana. Shrub density showed the reverse pattern of trees (density ranged from 27773.4 shrub/ha in close canopy to 30887.1 shrub/ha in open canopy) whereas no trend was found in herb density. The shrub density was significantly varied from one canopy cover to another canopy cover $(\mathrm{p}<0.01)$ (Table 1$)$.

The Shannon diversity index for tree species was increased (0.69 to 0.89 ) with decreasing disturbance. Similar results have been shown by herb species as they were highest in open canopy (4.11) forest followed by close canopy (4.06) and lowest in moderate canopy (4.09) forest. It was significantly varied from one canopy cover to another canopy $(\mathrm{p}<0.01)$. But in case of shrub species, the highest value (3.28) of Shannon diversity index was observed in moderate canopy followed by close canopy (3.22) and open canopy (2.89). It was significantly varied from moderateclose canopy $(\mathrm{p}<0.01)$. Simpson index for tree species also maximu $m$ in close canopy $(0.74)$ forest. Whereas in shrubs, Simpson index was $0.137,0.162$ and 0.194 for close canopy, moderate and open canopy forest. In herbaceous layer, the highest Simpson index (0.083) was recorded in close canopy forest. Evenness for tree species was highest in moderate canopy $(0.21)$ and it was recorded lowest $(0.12)$ at in intermediate level of disturbance. In case of shrub and herb evenness, the maximum values were observed in close canopy forest compared to moderate and open canopy forest (Table 1). The shrub richness was significantly decrease with increasing the tree crown cover and herb richness was increase with increasing the canopy cover (fig. 2).

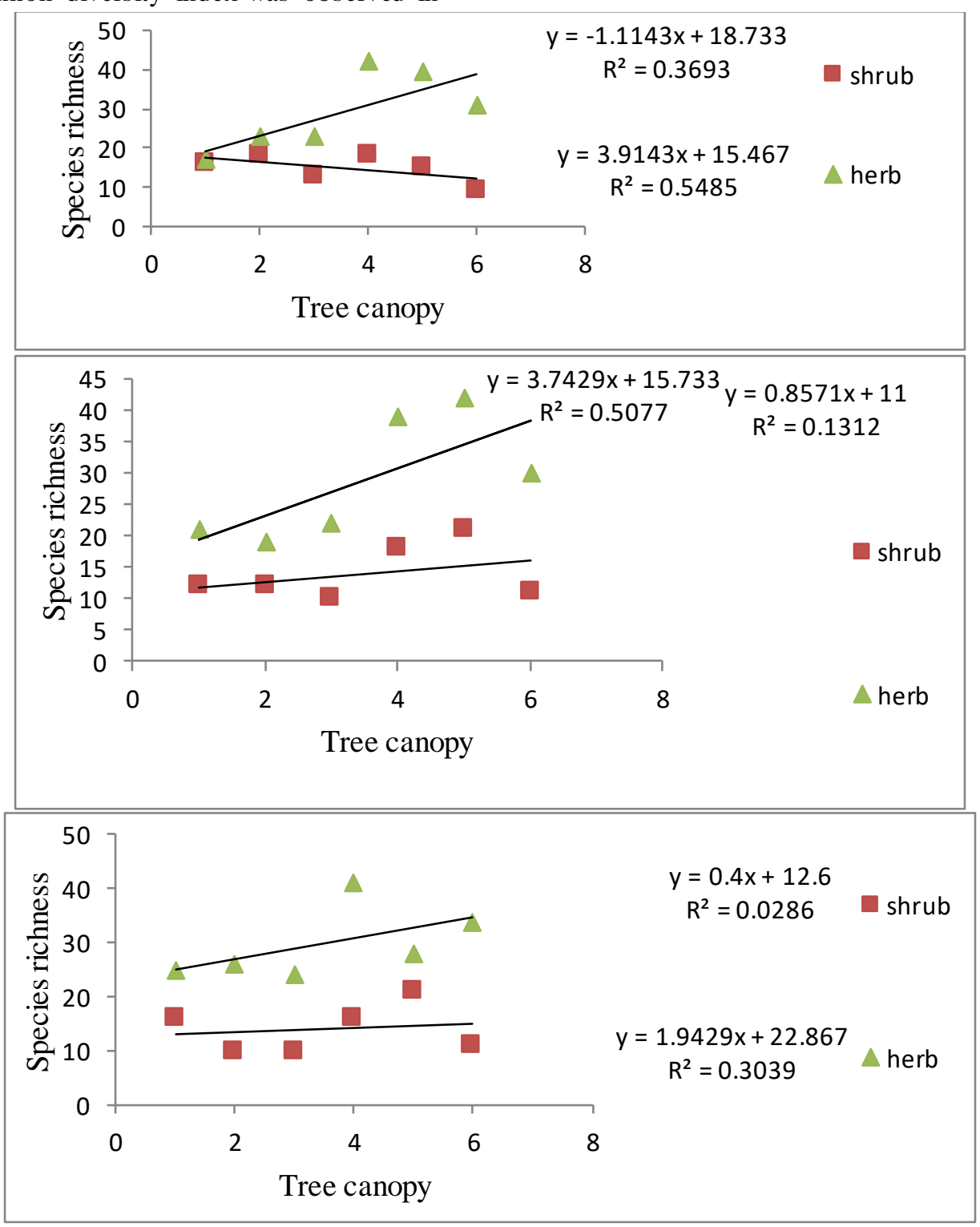

A. Open canopy B. Moderate canopy C. Close canopy

Fig.2: Relationship between tree canopy cover and shrub \& herb species richness in Pinus roxburghii forest 
The similarity index of tree indicated that the open canopy of mixed broadleaf forest and close canopy pine forest (77.78\%) were more similar as compared to moderate canopy of mixed broadleaf forest and close canopy of mixed broadleaf forest $(77.42 \%)$. The least similarity was showed in open canopy of pine forest and moderate canopy of mixed broadleaf forest (41.67\%) (Table2). In shrub, the similarity index indicated that the open canopy of mixed broadleaf forest and close canopy of mixed broadleaf forest (92.06\%) had high similarity compared to moderate canopy of mixed broadleaf forest and close canopy of mixed broadleaf forest (89.23\%). Moderate canopy of mixed broadleaf forest and close canopy of pine forest showed least similarity index (74.62\%) (Table 3). While, herb similarity index indicated that the moderate canopy of mixed broadleaf forest and close canopy of mixed broadleaf forest $(81.72 \%)$ have high similarity compared to moderate canopy of pine forest and close canopy of mixed broadleaf forest $(68.16 \%)$ (Table 4$)$.

\section{DISCUSSION}

Anthropogenic disturbances may also directly alter tree species diversity (Cayuela et al. 2006). The forest of Uttarakhand Himalaya are witnesses various disturbances which influence the distribution and composition of species in different canopy openings, forests and elevations. Loss of forest cover associated with human activities and lead to formation of Forest Island within a fragmented landscape. Both mixed broadleaf forest and $P$. roxburghii forest showed a declined in tree species richness with increasing level of disturbance. The stability increases with the comple xity of ecosystem, i.e with the number of species and with the number of interactions between them (Leigh 1965). In these forests, the stem density increased with increasing disturbance level. The high density of trees with close canopy provides moisture and humus, which are essential for the seed germination and growth of most of the shade bearer species. However, establishment and survival of all the seedlings also depends upon several other factors (Samant et al. 2002 and Joshi2002).

The mixed broadleaf forest and $P$. roxburghii forest behave differently in term of impact of disturbance on species richness, density and diversity. Tree species richness was high in mixed broadleaf forest compared to $P$. roxburghii forest. While, shrub and herb richness were high in $P$. roxburghii forest compared to mixed broadleaf forest. Species richness reported for $P$. roxburghii forest varied from 12-142 (Ram et al. 2004, Rawal 1991 and Chandra 1991). Similarly, 35-160 species were reported for mixed broadleaf forest (Ram 2005, 2004 and Khera et al. 2001). The divers ecological condition like variation in canopy www.ijeab.com cover, forest types, topography, soil and climate may favour the greater number of species in the area. Pant and Samant (2007) reported that high richness may be of diverse habitats and suitable edaphic and climatic factors supporting growth and survival of the species.

The density was significantly high in mixed broadleaf forest. Singh et al. (1994) have reported that density value ranging from 250-2070 trees/ha across a wide altitudinal range for the forests of Kumaun Himalaya. Shrub density was significantly high in $P$. roxburghii forest because pine is an early sucessional species with spreading canopy support the growth and development few shrubs. The herb density was high in mixed broadleaf forest because the soil mo isture favoured the occurrence of large number of herbaceous plant species and their population in the semiarid climate of western Uttar Pradesh (Sharma and Upadhayay 2002). Srivastava and Singh (2005) have reported that the growth of grasses were predominant at the disturbed site during rainy season. As a result of mild grazing, most graminoids grow by increasing their tillers and persist for long time with annuals and finally maintain higher cumulative density of perennials and annuals in grasslands.

The tree, shrub and herb diversity was high in mixed broadleaf forest compared to pine forest. Monk (1967) and Risser and Rice (1971) obtained 2-3 as the highest value for diversity index of temperate forest on the other hand, tropical forest indicated that higher diversity as calculated by Knight (1975) for Young $(\mathrm{H}=5.06)$ and Old $(\mathrm{H}=5.40)$ stands. Braum (1950) has reported that 1.69-3.40 value of tree diversity of certain temperate forest were lower than the value reported for tropical forest. The lower diversity of temperate vegetation could be due to lower rate of evolution of diversification of communities (Fisher 1960 and Simpson 1964). The diversity value for tree were in the range of 0.33-2.95 reported for most of the low elevational Central Himalayan forest (Saxena and Singh 1982, Ralhan et al. 1982, Upreti et al. 1985, Bargali et al. 1987, Tripathi et al. 1987 and Rikhari et al. 1991). The disturbance may play an important role in maintaining diversity in these forests. The effect of disturbance and resource availability on the abundance and diversity of herbaceous vegetation have been widely studied (Timothy et al. 1998). In Northern hard woods forests, large scale disturbance increase the abundance and diversity of ground vegetation by increasing resource availability (Bormann and Likens 1979, Hughes and Fahey 1991), but after several decades of stand development, the pattern of abundance of herbs appears to resemble those of the pre-disturbance forest (Reinors 1992). To conclude the mixed broadleaf forest is more conservative for tree species richness and overall diversity

Page | 159 
while shrub and herb richness are more in pine forest. These points should keep in mind while managing such Himalayan forests.

\section{REFERENCES}

[1] Arya, N. and Ram, J. 2013. Effect of canopy opening on soecies richness in $P$. roxburghii sarg. (chir-pine) forests in Uttarakhand Himalaya. Paripex Indian Journal of Research. Vol 1. ISSN: 2250-1991

[2] Bargali, S. S., Tewari, J. C., Rawat, Y. S. and Singh, S. P. 1987. Woody vegetation in blue pine-mixed oak forest of Kumaun Himalaya, India: In Y. S. Pangtey and S. C. Joshi (eds.), Western Himalaya: Environmemtal problems and development. Pp. 121135, Gyanodaya Prakashan, Nainital.

[3] Bormann, F. H. and Likens, G. E. 1979. Pattern and processes in a forest ecosystem. Springer-Verlag, New York, U. S. A.

[4] Braun, E. L. 1950. The ecology of the forest of Eastern North America, their development, composition \& distribution deciduous forest of Eastern North America. Mc Graw Hill (New York: Blakiston).

[5] Cayuela, L., Golicher, D.J., Renoyas, J.M.R., Espinosa, M.G. and Marcial, N.R. 2006. Fragmentation, disturbqance and tree diversity conservation in tropical montane forests. Journal of Applied Ecology. 43: 1172-1181.

[6] Chandra, R. 1991. An altitudinal pattern of woody vegetation along water courses in part of Kumaun Himalaya. Ph. D. thesis, Kumaun University, Nainital.

[7] Curtis, J.T. and McIntosh, R.P. 1950. The interrelationship of certain analytic and synthetic phytosociological characters. Ecology, 31: 438-455.

[8] Dhaulakhandi, M. 1996. A study on structure, Phytosociology and regeneration of an oak forest of Bhagirathi Valley, Garhwal Himalaya. Ph. D. Thesis Garhwal university, Srinagar (Garhwal).

[9] Fisher, A. G. 1960. Latitudinal variation in organic diversity, Evolution, 14: 64-81.

[10] Giri, D., Tewari, A. and Rawat, Y. S. 2008. Vegetation Analysis in mixed banj ( $Q$. Leucotrichophora A. Camus) Tiloj-oak ( $Q$. floribunda Lindl.) forest in nainital catchment, Indian Journal of Forestry, Vol. 32(2): 167-174.

[11] Hughes, J. W. and Fahey, T. J. 1991. Colonization dynamics of herbs and shrubs in a disturbed northern hardwood forest. Journal of Ecology, 79: 605-616.

[12] Joshi, H.C. 2002. Assessment of habitat diversity. Forest vegetation and human dependence in Buffer Zones of Nanda Devi Biosphere Reserve of West
Himalaya. Ph. D Thesis submitted to Kumaun University, Nainital.

[13] Kalakoti, B. S., Pangtey, Y. P. S. and Saxena, A. K. 1986. Quantitative analysis of high baltitude vegetation of Kumaun Himalaya. J. India, Bot. Esc. 65: 384-396.

[14] Kharkwal, G. 2002. Spatial Pattern of Plant Species Diversity with particular reference to forest herbs along an altitudinal transect in Central Himalaya. Ph. D. thesis Kumaun University, Nainital.

[15] Khera, N. Kumar, A. Ram, J. and Tewari, A. 2001. Plant biodiversity assessment in relation to disturbances in mid elevational forest of Central Himalaya, India. Tropical Ecology, 42: 83-95.

[16] Khera, N., Kumar, A., Ram, J. and Tewari, A. 2001. Plant biodiversity assessment in relation to disturbances in mid elevational forest of Central Himalaya, India. Tropical Ecology, 42: 83-95.

[17] Knight, D. H. 1975. A phytosociological analysis of species rich tropical forest of Barro Colorado Island, Panama. Ecological Monograph, 45: 259-284.

[18] Kumar, A. 2000. Plant biodiversity in forests of middle Central Himalaya in relation to various disturbances. Ph. D. thesis, Kumaun University, Nainital.

[19] Kumar, A. and Ram, J. 2005. Anthropogenic disturbances and plant biodiversity in forests of Uttaranchal, Central Himalaya. Biodiversity Conservation. 14, 309-331.

[20] Kumar, A. and Ram, J. 2005. Anthropogenic disturbances and plant biodiversity in forests of Uttaranchal, Central Himalaya. Biodivers. Conserv. 14: 309-331.

[21] Lal Manohar. 2007. Assessment of diversity and conservation status of plants in Kasi Wildlife Sanctuary of Himalaya, $\mathrm{Ph}$. D. thesis Kumaun University, Nainital (India).

[22] Leigh, E. 1965. On a relation between the productivity biomass, stability and diversity of a community. Proc. Natl. Acad. Sci. USA. 53: 777-783.

[23] Mishra, B. P., Tripathi, O. P., Tripathi, R. S. and Pandey, H. N. 2004. Affect of anthropogenic disturbance on plant diversity and community structure of a sacred grove in Meghalaya, North East India. Biodiversity Conservation, 13: 421-436.

[24] Monk, C. D. 1967. Tree species diversity in the eastern deciduous forest with particular reference to North Central Florida. Am. Nat. 101: 173-187.

[25] Neeta Arya, Beena Tewari and Jeet Ram. 2012. The effect of natural and anthropogenic disturbance in forest canopy and its effect on species richness in 
forests of Uttarakhand Himalaya, India. Russian Journal of Ecologz. Vol 43, pp 117-121. (ISSN: 10674136).

[26] Pathak, M. C., Bargali, S. S. and Rawat, Y. S. 1993. Analysis of woody vegetation in a high elevation oak forest of Central Himalaya. Indian Forester. 722-731 pp.

[27] Pausas, J.G., Lloret, F. and Montserrat, V. 2006. Stimu lating the effect of different disturbance regimes on cortaderia selloana invasion. Bio. Conserv. 128: 128-135.

[28] Pielou, E.C. 1966. The measurement of diversity in different types of biological collections. J. Theor. Biol., 13, 131-144.

[29] Ralhan, P. K., Saxena, A. K. and Singh, J. S. 1982. Analysis of forest vegetation in and around Nain ital in ku maun Himalaya. Proc. Indian Natl. Science Acad, 48: 122-138.

[30] Ram, j., Kumar, A. and Bhatt, J. 2004. Plant diversity in six forest types of Uttaranchal, Central Himalaya, India. Current Science. Vol. 86: 975-978.

[31] Ram, Jeet, Tewari, Beena and Arya, Neeta. 2005. Variation in plant biodiversity of chir-pine and banjoak forests of Uttaranchal Himalaya. 54-56 pp. In Muthuchelian (ed.). Biodiversity resources management and sustainable use. Centre for biodiversity and forest studies, Madurai.

[32] Rawal, R. S. 1991. Woody vegetation analysis along an elevational gradient of upper surju catchment. $\mathrm{Ph}$. D. thesis, Kumaun University, Nainital.

[33] Reiners, W. A. 1992. Twenty years of ecosystem reorganization following experimental deforestation and regrowth suppression. Ecological Monographs, 62: 53-523.

[34] Rikhari, H. C., Tewari, J. C., Rana, B. S. and Sharma, S. 1991. Woody vegetation and regeneration status in a mixed oak forest of Kumaun Himalaya. Indian Forester. 117: 274-283.

[35] Risser, P. G. and Rice, E. L. 1971. Diversity in tree species in Oklahoma upland forests. Ecology. 52: 876-880.

[36]Sagar, R. and Singh, J. S. 2005. Structure, diversity and regeneration of tropical dry deciduous forest of northern India. Biodiversity and Conservation. 14: 935-959.

[37] Samant, S. S. and Joshi, H. C. 2005. Plant diversity and conservation status of Nanda Devi National park and comparisons with highland National parks of India Himalayan region. International journal of biodiversity Science and Management. 1: 65-73 pp.
[38] Samant, S.S., Joshi, H.C., Arya, S.C. and Pant, S. 2002. Studies on the structure, composition and changes of the vegetation in Nanda Devi Biosphere Reserve of West Himalaya- Final Technical report submitted to Ministry of Environment and Forest, New Delhi.

[39] Saxena, A.K. and Singh, J.S. 1982. A phytosociological analysis of woody species in forest communities of a part of Kumaun Himalaya. Vegetatio. 50: 3-22.

[40] Semwal, S. 2006. Studies on phytosociology, Diversity patterns and composition along an altitudinal gradient in a part of lesser Himalaya, Garhwal, Uttarakhand, Ph. D thesis, H. N. B. Garhwal University, Srinagar, Garhwal, uttarakhand, India.

[41] Shannon, C.E. and Weaver, W. 1963. The Mathematical theory of communication. University of Illinois Press, Urbana.

[42] Sharma, K. P. and Upadhaya, B. P. 2002. Phytosociology, primary production and nutrient retention in herbaceous vegetation of the forestry arboretum on the Aravalli hills at Jaipur. Tropical Ecology, 43: 325-335.

[43] Simpson, E. H. 1964. Species diversity of North American recent Mammals. Syst. Zoo., 13: 57-73.

[44] Simpson, E.H. 1949. Measurement of Diversity. Nature, 163: 688.

[45] Singh, J. C. and Singh, S. . 1987. Forest vegetation of the Himalaya. Bot. Rev. 53: 80-192.

[46] Singh, J. S. and Singh, S. P. 1992. Forest of Himalaya. Structure and Functioning and Impact of man. Gynodya Prakasha, Nainital, India.

[47] Singh, J. S., Singh, S. P. and Gupta, S. R. 2008. Ecology environmental and Resource Conservation, Anamaya Publishes, New Delhi. 688pp.

[48] Singh, N., Tamta, K., Tewari, A. and Ram, J. 2014. Studies on vegetational analysis and regeneration status of Pinus roxburghii Roxb. and Quercus leucotrichophora forests of Nainital forest Division. Global Journal of Science FrontierResearch: C Biological Science. Vol 1. ISSN: 2249-4626.

[49] Singh, S. P., Adhikari, B. S. and Zobel, D. B. 1994. Ecol. Monogr. 64: 401-421.

[50] Singh, S.P. 1998. Chronic disturbances, a principal cause of environmental degradation in developing countries. Environ. Conserv. 25, 1-2.

[51] Srivastava, R. and Singh, K. P. 2005. Species diversity in dry land and irrigated agro ecosystem and marginal grassland ecosystem in dry tropics. Community Ecology, 6: 131-141. 
[52] Sundriyal, R. C. and Bisht, N. S. 1988. Tree structure, regeneration and survival of seedlings and sprouts in high montane forest of the Garhwal Himalayas, India. Vegetation. Vol. 75: 87-90pp.

[53] Tewari, J. C. and Singh, S. P. 1981. Vegetational analysis of a forest ly ing in transitional zone between lower and upper Himalaya moist temperate forest. Pp. 14-119. In: G. S. paliwal (eds.). The vegetational wealth of Himalaya. Priya Publishes, New Delhi.

[54] Tewari, J. C., Ricardi, H. C. and Singh, S. P. 1989. Compositional and structural features of certain tree stand along an elevational gradient Central Himalaya. Vegetatio. 85: 117-120.

[55] Timothy, J. F., John, J. B. and Geoffrey, F. W. 1998. Responses of early sucessional Northern hardwood forests to changes in nutrient availability. Ecological Monographs, 68 (2): 183-212.

[56] Tripathi, B. S., Rikhari, H. C. and Singh, R. P. 1987. Dominance and diversity distribution in certain forest of Kumaun Himalayas, IX International symposium on tropical ecology, 235pp.

[57] Upreti, N., Tewari, J. C. and Singh, S. P. 1985. The oak forests of the kumaun Himalaya (India) 1: Composition, diversity and regeneration. Mountain Research and Development, 5 (2): 163-174.

[58] Valdiya, K.S. 1980. Stratigraphic scheme of the sedimentary units of the Kumaon lesser Himalaya. In: Valdiya K S, Bhatiya S B (eds.) Stratigraphy and correlation of the lesser Himalayan formations. Hindustan Publication Corporation, Delhi, India, Pp 7-48.

[59] Whittaker, R.H. 1972. Evolution and management of species diversity. Taxon 21: 213-251.

[60] Whittaker, R.H. 1975. Communities and ecosystems. $2^{\text {nd }}$ ed. Macmillan Pub. Co., New York, 385 pp. 